\title{
Entrepreneurship Module in Community Colleges Malaysia
}

\author{
Rasmuna Hussain and Norasmah Othman
}

\begin{abstract}
The needs in developing the knowledgeable and skillful human capitals are vital. The government plans to be more organized on education system in order to improve the quality of training and skills and enhance the lifelong learning programs. Interests and concerns about the subject of entrepreneurship have been highlighted among education and training especially higher learning institutions. This study aims to assess the implementation of the Basic Entrepreneurship Module (BEM), which was implemented in Community College, Ministry of Higher Education (MoHE) based on the CIPP Model in the three components of evaluation. Input evaluation is to observe the students' and lecturers' perspectives towards implementation of BEM. Product evaluation is to observe the achievement levels of entrepreneurial behavior in terms of cognitive and non-cognitive aspects. The data was collected from 105 students and 42 lecturers of the Business Accounting Certificate program at six community colleges. The survey instrument used is in the form of questionnaires, which were then analyzed using descriptive statistics method. The findings showed that overall respondents agreed that the implementation of BEM in terms of input and product evaluation were at moderately high and high levels.
\end{abstract}

Index Terms-Entrepreneurship module, entrepreneurial behavior, evaluation, community colleges.

\section{INTRODUCTION}

Entrepreneurship is very crucial for every economy [1]. A country in strong entrepreneurs with entrepreneurial attitudes can be more successful in their business [2]. [3] stressed that to meet the economic needs of the 21 st century, a change in the education system towards the entrepreneurship or 'entrepreneurially-driven' is really important. Although entrepreneurship education and training increasingly featured as one of the important agenda of education, and has gained a place in higher education institutions and schools, many researchers think that education and entrepreneurship in the country is still less favorable than in western countries [4], [5]. The effectiveness of entrepreneurship education and training programs need the concept of the true state of the world of entrepreneurship in teaching and learning approaches [6].

Lifelong learning program is enhanced with the upgrading skills and reskilling offered by various educational and training institutions like community colleges. In Budget 2011, human capital development has become the main

The manuscript received August 20, 2013; revised September 20, 2013. Rasmuna Hussain is with the Business Accounting Education at the Kuala Langat Community College, Selangor (e-mail: rust_moon@yahoo.com.my)

Norasmah Othman is with in Business and Entrepreneurship Education at Faculty of Education, Universiti Kebangsaan Malaysia, Bangi, Malaysia (e-mail: rasmuna@kkkla.edu.my). essence through the implementation of a training program of 1Malaysia. Since its inception in 2001, Community Colleges give the opportunity to post-secondary students in education and training through the full-time and part-time technical and engineering programs. In addition, community colleges also provide skills and training in entrepreneurship through a lifelong learning program. Today in 10th Plan, a total of RM500 million is allocated to institutions such as community colleges and others. Thus, community colleges have played a large role in reskilling and upskilling programs in which benefits to 507,940 participants. Thus, the government has targeted that community colleges' total enrollment will increase from 31,000 students in 2010 to 120,000 students by 2014 [7].

In addition, MoHE has taking step in the implementation of the National Higher Education Strategic Plan (NHESP) for the period from 2008-2010 [8] on enhancing human capital development to empower higher education. A major strategy in the implementation of the NHESP's second core through the plan of improvement in the quality of teaching and learning, has been placed the community college to a major challenge to improve the quality of human capital that is knowledgeable, competent and able to meet market demands. The challenges start with the development of the curriculum in accordance with market needs and the dynamic changes of teaching and learning methods. Teaching and learning culture must change and transform in producing the quality of human capital such excellent knowledge, skills, creative and innovative. MoHE also put a few key performance indicators (KPI) and one of them is accelerating entrepreneurship education programs in universities, polytechnics and community colleges.

\section{LITERATURE REVIEW}

Entrepreneurship education programs should foster self-confidence and increase the value of self-esteem of students. Self-confidence is an important component to become a successful entrepreneur. Educating the students that the entrepreneur can come from various backgrounds and provides students with a positive view of the tremendous opportunities available in the future and this is an important aspect of an entrepreneurship course. Entrepreneurial skills acquired can be applied in all forms of employment or career and social welfare. It is important in explaining to students that entrepreneurship is not merely the start and opened a business only. In fact, a person employed by a business entity can apply entrepreneurial thinking in the internal functions of the business [6]. As [2] agreed that the entrepreneur's entrepreneurial attitudes and thinkings are very much influenced by their age and engagement in the enterprises. 
In the first five years of $9^{\text {th }}$ Plan (2006-2010), where the National Mission (2006-2020) in the core of the second government plans to increase capacity and innovation and nurture first class mentality by encouraging technology entrepreneurs. Technology-based enterprises and improved technology incubator programs for entrepreneurs in order to develop sustainable technologies is part of the efforts to nurture a Bumiputera Science and Technology. In consistent with that, some universities have increased the efforts in producing knowledgeable and skilled people in entrepreneurship. These are ultimately realizing the National Mission to develop human capitals with first class mentality.

In $10^{\text {th }}$ Plan, the government is committed in developing creativity through initiatives such as mainstreaming of technical education and vocational training (TVET) to improve skills and quality of students. Entrepreneurship education curriculum was introduced to instil an element of innovation to stimulate entrepreneurship in education programs at several higher learning institutions either as a compulsory or an elective subject. Entrepreneurship curriculum and training model has been redrafted and built to enhance the knowledge and skills for various target groups. There are studies that have been conducted to see the acceptance of students from various fields of engineering and technology found they agreed to accept the subject of entrepreneurship as an elective subject or absorb into the programs [9].

\section{Problem Statement}

In 2010 a total of 7,672 at the community college graduate with certificates and diplomas in order to meet the job market in a various sectors. A graduate tracer studies have been conducted by the Department of Polytechnic and Community College Education, DPCCE, MoHE in 2010 showed 53.1\% community colleges graduates have been successful in pursuing their careers in respective fields. Tracer studies of community college graduates have been carried out starting in 2003 for obtaining feedback on the study and assess the employability of community college graduates.

The community college students graduate with skills in various fields of engineering and technical whom to be self-employed in the field of entrepreneurship is still less favorable. Graduates Tracer Study of Polytechnic and Community College in 2008 has shown the number of the community college graduates obtained employment was $1,797(48.6 \%)$ while the number of those who do not work was $1,432(38.7 \%)$. However, $56.7 \%$ of those who do not work stated that they are still looking for a job in the study. Community College Tracer Study Report 2010 shows the number of people who get involved in entrepreneurship by running their own company has the second highest number of $15.7 \%$ after working in the local private sector by $64.7 \%$.

Implementation of entrepreneurship education and training programs in community colleges have a great impact on the number of self-employed graduates whom engaged in entrepreneurship is only $4.1 \%$. Even so, they stated a higher aspiration to become entrepreneurs which is $75.8 \%$ [10]. Therefore, community college students are the target groups should be given attention and emphasis on increasing opportunities and entrepreneurial skills training program implemented by the government today. Moreover, community college graduates are the youth of the future entrepreneurs generation whom need to inculcate values, attitudes, knowledge and excellent skills in order to generate economic development of the country in the future. Hence, this study is aim to explore how far the human resources evaluate the entrepreneurships educational program that is Module Basic Entrepreneurship.

\section{Methodology}

This evaluation study conducted in the form of a quantitative approach. There are 144 community college students pursuing Business Accounting Certificate program in ten community colleges and undertaking an entrepreneurship education and training that is MBE in their final semester. However, researcher will take samples of students from the colleges such as Kulim Community College Kedah, Kuala Langat Community College Selangor, Selandar Community College Malacca, Bentong Community College Pahang, Pasir Gudang Community College Johore and Pasir Mas Community College, Kelantan.

This study used questionnaires as the research instrument. Questionnaires are used in the evaluation of inputs, processes and products. Data were collected from a sample of 105 students and 42 lecturers. Analysis of data is created using the package SPSS for Windows version 11.5. Descriptive statistics based on frequencies and percentages to describe the background of the respondents while the size of central tendency (mean) and measure of variability (standard deviation) are used to see the perception of lecturers and students on the implementation of BEM in community colleges.

\section{FINDINGS}

Data obtained from 105 respondents, 60.9\% (n=64 persons) of respondents were female and $39.1 \% \quad(n=41$ persons) of respondents were male. From the 105 respondents, the majority of $70.5 \%$ ( $n=74$ persons) has not been pursuing a course / training in entrepreneurship, while a total of $29.5 \%$ ( $n=31$ persons) respondents who had attended any courses / training in areas related to the findings entrepreneurship. Majority of lecturers are females, $88.1 \%$ ( $n=37$ persons) and $11.9 \%$ ( $n=5$ persons) are males. $61.9 \%$ ( $n=26$ persons) possess degree, with $73.8 \%$ ( $n=31$ persons) is categorized in business education and $26.2 \%$ ( $n=11$ persons) in other areas.

The result covers two respondents' perspectives towards BEM. The milestones of their perceptions is the result of evaluation of BEM in the input evaluation can be referred to the mean score interpretation adapted from [11] as follows:

Mean score of 1:00 to 2:00 is low level.

Mean score of 2:01 to 3:00 is moderately low level.

Mean score of 3:01 to 4:01 is moderately high level.

Mean score of 4:01 to 5:00 is high level.

\section{A. Input Evaluation}

\section{1) Lecturers' perspectives}

In this study, the level of lecturers' perspectives was measured by ten questions as a whole. According to Table I 
below, the respondents agreed that the item, C2 "kin on teaching BEM" is the most robust at 4.02 and a standard deviation of 0.75 . For items, C9 "Basic infrastructure is prepared adequately" has a mean lower mean of 3.45 and 0.67 of standard deviation.

Overall findings indicate items on the lecturers' perceptions in the input evaluation shows the mean score of students at the moderately high level of 3.73 and 0.69 of standard deviation. This means that lecturers have a moderately good perception and ability towards performing the task of teaching and learning BEM.

TABLE I: LEVEL OF LECTURERS’ PERSPECTIVES TOWARDS IMPLEMENTATION OF BEM

\begin{tabular}{llclr}
\hline \multicolumn{4}{c}{ IMPLEMENTATION OF BEM } \\
\hline Item & Mean & SD & Intp. \\
C9 & $\begin{array}{l}\text { I am very kin on } \\
\text { teaching BEM }\end{array}$ & 4.02 & 0.75 & $\mathrm{H}$ \\
& $\begin{array}{l}\text { The infrastructure is } \\
\text { prepared adequately } \\
\text { when teaching BEM }\end{array}$ & 3.45 & 0.67 & $\mathrm{MH}$ \\
\hline & Overall Mean (10 items) & $\mathbf{3 . 7 3}$ & $\mathbf{0 . 6 9}$ & $\mathbf{M H}$ \\
\hline
\end{tabular}

\section{2) Students'perspectives}

Besides lecturers' perspectives elements, there are students' perceptions elements in this study which were measured by ten questions also. According to Table II, item D5 "Many new things being learned" showed the highest mean of 4.35 and standard deviation of 0.72 . Respondents agreed that the item, D7 "Time allocated for BEM is adequate" is the lowest mean at 4.06 and standard deviation 0.73 .

Therefore, the overall findings of the study showed those items on the students' perceptions in input evaluation shows the mean score of students at the high level of 4.21 and 0.68 of standard deviation. This means that students have a very good perceptions and confidence towards implementation of BEM. They believe that BEM could enrich their entrepreneurial behaviors in future.

TABLE II: LEVEL OF STUDENTS' PERSPECTIVES TOWARDS IMPLEMENTATION OF BEM

\begin{tabular}{llccc}
\hline \multicolumn{4}{c}{ IMPLEMENTATION OF BEM } & \\
& Item & Mean & SD & Intp. \\
\hline D & I learned many new things & 4.35 & 0.72 & $\mathrm{H}$ \\
5 & & & & $\mathrm{H}$ \\
D & Time is allocated adequately for & 4.06 & 0.73 & \\
7 & BEM & $\mathbf{4 . 2 1}$ & $\mathbf{0 . 6 8}$ & $\mathrm{H}$ \\
\hline & Overall Mean ( 10 items ) & & & \\
\hline
\end{tabular}

\section{B. Product Evaluation}

\section{1) Cognitive entrepreneurial behavior}

In this study, the level of cognitive entrepreneurial behavior were measured by twenty questions as a whole. According to Table III below, the respondents agreed that the item "I think that entrepreneurs should be capable of preparing a business plan" is the most robust at 4.41 and a standard deviation of 0.549 . For items "I can be a model to others" has a mean lower mean of 4.12 and 0.60 of standard deviation.

Overall findings indicate items on the achievement of product evaluation in the cognitive aspects of entrepreneurial behavior shows the mean score of students at the high level of 4.29 and 0.58 of standard deviation. This means that students have the cognitive behavioral of a very good entrepreneurial.

TABLE III: LEVEL OF COGNITIVE ENTREPRENEURIAL BEHAVIOR CogNITIVE

\begin{tabular}{llccc}
\hline & Item & Mean & SD & Intp. \\
\hline J2 & $\begin{array}{l}\text { I think that entrepreneurs should } \\
\text { be capable of preparing a } \\
\text { business plan. }\end{array}$ & 4.41 & 0.55 & H \\
J7 & $\begin{array}{l}\text { I can be a model to others. } \\
\text { Overall Mean (20 items) }\end{array}$ & 4.12 & 0.60 & H \\
\hline
\end{tabular}

\section{2) Non-cognitive entrepreneurial behavior}

Besides cognitive behavioral elements, there are non-cognitive behavioral elements in this study which were measured by twenty-five questions. According to Table IV, item I think that "to become a successful entrepreneur I have to use my weakness and strength" showed the highest mean of 4.34 and standard deviation of 0.586 . Respondents agreed that the item "I only venture into a successful business in the future" that is at min 4.01 and standard deviation 0.753 .

Therefore, the overall findings of the study showed those items on the achievement of product evaluation in the cognitive aspects of entrepreneurial behavior shows the mean score of students at the high level of 4.16 and 0.67 of standard deviation. This means that students have a very good entrepreneur non-cognitive behavioral.

TABLE IV: LEVEL OF NON-COGNITIVE ENTREPRENEURIAL BEHAVIOR

\begin{tabular}{llccc}
\hline & Item & Mean & SD & Intp. \\
\hline K8 & $\begin{array}{l}\text { I always defend my opinion if } \\
\text { Komeone else does not agree. }\end{array}$ & 4.00 & 0.809 & $\mathrm{H}$ \\
& $\begin{array}{l}\text { I think that to become a } \\
\text { successful entrepreneur I } \\
\text { have to use my strengths and } \\
\text { weaknesses. }\end{array}$ & 4.34 & 0.586 & $\mathrm{H}$ \\
\hline & Overall Mean (25 items ) & $\mathbf{4 . 1 6}$ & $\mathbf{0 . 6 6 8}$ & $\mathrm{H}$ \\
\hline
\end{tabular}

\section{DISCUSSION}

\section{A. The Aspects of Input Evaluation}

In curriculum development programs, results and the need for the supply of subjects take into account the topics that have direct relevance to the scope of the requirements of a career skills and discipline. Entrepreneurship education curriculum should be developed that combines business education-oriented emphasis on career skills required in business. As [12] says that an entrepreneurship education are able to influence students to choose entrepreneurship as a career. Content in the subject offered that is Basic Entrepreneurship Modules (BEM) must be relevant to the needs of the formation and development of entrepreneurial behavior in students.

The result showed that the mean score for the item of interest is teaching BEM is the highest mean of 4.02 and standard deviation of 0.75 . Mean scores for items lecturer in the basic facilities needed to teach the BEM is 3.45 and the standard deviation of 0.67 which is lower than the mean overall perceptions of lecturers towards BEM. The findings showed that community colleges faculty have a moderate 
interest to teach the BEM. Although the level of the lecturers on the BEM content showed moderately high, facilities needed to teach this module is still not satisfactory.

However, the perception of lecturers on the BEM as a whole is moderately higher at the mean level of 3.73 and standard deviation of 0.69 . Concluded that community colleges lecturers have good views and ability in implementing the Basic Entrepreneurship Module to students. This study is consistent with the findings [13] for evaluating the implementation of Islamic Education Curriculum at Polytechnic MoHE reflects the assessment of input dimension in Islamic Studies lecturer at a moderate level in which the lecturer to view the content of Islamic education modules based on their knowledge of the content. Similarly, this research study equal [14] in the evaluation input indicates that the confidence of teachers of subjects found to be effective teachers and teaching skills, training, equipment and workshops are not effective.

The result is that students strongly agreed that they learned new things through BEM shows the highest mean score of 4.35 and standard deviation of 0.72 . Students stated that the provision of adequate learning time is 4.06 mean score and standard deviation of 0.73 . However, the mean is lower than the overall mean. Students' perception of BEM was generally high level of 4.21 and standard deviation of 0.68 . This means that community college students agreed that their exposure to entrepreneurship module and it is very necessary to develop the entrepreneurial behavior in them fully. These findings support the study of [13] who found that students' perceptions of Islamic education at the highest level and they said the perception is based purely on the module because of what they earn from the module is new information.

Theory of attitudes and behaviors related to [15] touched on the perception that an internal assumptions, attitudes, behavior and behavior can be changed. Thus, perceptions and attitudes towards business education or entrepreneurship can be an impact on the achievement level of students' behavior with the action taken in these subjects. Perception and the ability of a good lecturer in implementing the Basic Module Entrepreneurship to students with the facilities provided will influence the perceptions of students in the state acquired learning can develop the necessary entrepreneurial behavior by them. Methods of teaching and learning activities can encourage students to be motivated in applying the business environment [16]. Therefore, this study can confirm the prediction that the assessment of human resource input, student and lecturer in entrepreneurship education and training modules have been affecting the performance evaluation module. Their perception of a high valuation will have an impact on student achievement in terms of results required in the development of entrepreneurial behavior among the students better.

\section{B. The Aspects of Product Evaluation}

The findings indicate that entrepreneurial behavior among college students is high in terms of both cognitive and behavioral non-cognitive. Overall behavior of the items of cognitive and non-cognitive behavioral mean score indicates a high average. Cognitive behavior shows the mean scores between 4.01-5.00 in which the cognitive behavior of student entrepreneurship is high. In the context of this research, including cognitive behavioral knowledge possessed by students in matters related to the knowledge of the functions of his career, goal formulation, planning and problem solving.

The findings of this study match the findings of the study [11] which also shows the level of the overall student entrepreneurial behavior are high, particularly in the dimensions of knowledge work and planning function, but moderate in the formulation of goals and solve problems. As [17] says that a person will have deep knowledge about entrepreneurship if they get more exposure through education or training in these areas. Community college students have high knowledge on entrepreneurship after given exposure through entrepreneurship module.

Further findings from this study are also consistent with the studies by [15] who showed cognitive behavioral entrepreneurship among Aboriginal youth in Peninsular Malaysia is high. The findings of the study also found that respondents have a high mean score (4.23) in the element of start a business. The study also shows community college students have a deep knowledge of business must be capable of providing a business plan (4.41). As a whole before starting a business matter of high concern include the ability to provide good business plan and effective.

If the findings of this study is to measure the index percentage of entrepreneurial behaviors, the study findings will also show the community college has a high percentage of the index. Further findings will match the findings of the study by [11] who found that the dimensions of knowledge about the functions of his career is high for students from institutions of higher learning. Students from the training center also has index percentage in the formation of a higher goal than university students. Thus, community college students who are also students of higher education institutions of education and training is also a high percentage index in all aspects of cognitive behavioral.

From these findings it is proposed that exposure to entrepreneurship education and skills training should be given to all community college students based on the needs of today's economy. All these efforts will allow the existence of many more young entrepreneurs [18].

The study also looked non-cognitive behavioral outcomes for students of entrepreneurship. Overall behavior items of non-cognitive mean score indicates a high average. Non-cognitive behavior shows the mean scores between 4.01-5.00 where as entrepreneurial behavior for students is also high. Behavioral items of non-cognitive is embracing the external control factors, internal control self-tolerance of ambiguity and can be controlled by others and self-assessment.

Attitudes and characteristics include all the features necessary for entrepreneurship is such as far-sighted entrepreneurs, optimism, a desire to succeed, not satisfied with what is seen by others and did not hesitate for a point to be involved in, confident, freedom, self-reliant, creative and innovative. Non-cognitive behaviors are a characteristic of a special entrepreneurship which cannot be taught by others [19].

The study found that students felt that to become successful entrepreneurs need to use the weakness and strength showed the highest mean of 4.34 and 0.586 standard deviation. These findings are consistent with the studies by [15] who also found that the behavior of entrepreneurial 
non-cognitive in all aspects of behavior. [20] also believes that those who know the strengths and weaknesses before engaging in business can be an individual who has the potential to succeed.

The findings of this study also found that the respondents agreed that the item I only venture into a successful business in the future at min 4.01 and standard deviation 0.753 . This indicates that the student agree that to become entrepreneurs but not to become a successful entrepreneur, even though it is possible to achieve. Students felt that an entrepreneur should be adventurous and take risks to become a successful entrepreneur. According to [21] entrepreneurs who have a level of high internal locus of control will take action to change himself and the environment around them to achieve a successful business venture through action on the opportunities that exist. Therefore, it is very important in the students to prepare and strengthen themselves with the knowledge and the necessary entrepreneurial skills.

\section{CONCLUSION}

The culture of teaching and learning in community colleges need to be changed and transformed in order to produce the quality of human capital, excellent knowledge and skills that can generate socio-economic improvement and community with a high income. The students of community colleges have to increase their confident so that they can build up their enterprising skills in which is the most important parts of an entrepreneurship [1] and become successful entrepreneurs.

This study is also expected to be leveraged by the students in enhancing entrepreneurial skills and knowledge acquired during the exposure study at another institutions. Next it will provide guidance to educators, particularly at community colleges to develop entrepreneurial behaviors and thus can be applied to students during the teaching and learning process.

\section{ACKNOWLEDGMENT}

Rasmuna Hussain thanks for financial supported by the Department of Sponsorhips under the Ministry of Higher Education (MoHE) Malaysia as the sponsor throughout the research. Also thanks to the Chief Director of Department of Community Colleges Education and to all Directors of selected community colleges because give permission a lot of support for conducting the research afar. Finally, thanks to the chosen students for answering the questionnaires.

\section{REFERENCES}

[1] H. P. Bulsara, S. Gandhi, P. D. Porey, "A comparative study of enterprising tendency with the help of Select cases in India," International Journal of Trade, Economics and Finance, vol. 1, no. 4, pp. 392-399, 2010.

[2] G. Tamizharasi, N. Panchanatham, "An empirical study of demographic variables on entrepreneurial attitudes," International Journal of Trade, Economics and Finance, vol. 1, no. 2, pp. 215-220, 2010.

[3] C. M. Bridges, "Entrepreneurship education and economic development: preparing the workforce for the twenty-first century economy," Ph.D. Dissertation, South Carolina, USA, 2008.

[4] M. F. M. Jani, N. Othman, A. A. M. Ariffin, A. Zainal, I. H. Abdullah et al., "Jurang analisis pendidikan keusahawanan di IPTA dan usahawan berjaya," MoHE Research Report, 2007.
[5] N. A. Buang and H. Agil, "Tahap amalan pengurusan perniagaan di kalangan Usahawan Wanita Bumiputera," National Seminar On Islamic Entrepreneurship, Universiti Malaya, 2005.

[6] M. L. D. W. Kourilsky, "W. B. entrepreneurship and female youth: knowledge, attitudes, gender differences dan education practice. Journal of Business Venturing, vol. 13, no. 1, 1998, pp. 77-88.

[7] The Tenth Malaysia Plan 2011-2015, Kuala Lumpur, 2010.

[8] Ministry of Higher Education Malaysia, National Higher Education Strategic Plan (NHESP): Beyond 2020, Ministry of Higher Education, 2008.

[9] A. Mohamed, S. Ishak, and N. Hashim, "Perkembangan pendidikan keusahawanan dalam institusi pendidikan di Malaysia: Satu tinjauan," in Proc. 2nd National Entrepreneurship Conf., Vistana Hotel, Pulau Pinang. Disember 9-10, 2006.

[10] Ministry of Higher Education Malaysia Tracer Studies on Graduates of Community Colleges Year 2006, Department of Polytechnic and Community College Educatuion, DPCCE. Ministry of Higher Education, 2007.

[11] N. H. Othman, F. K. H. Harun, Z. A. L. Pihie, and N. A, Buang "Pembentukan indeks tingkah laku keusahawanan golongan remaja Malaysia," Final Report on IRPA Project.07-02 - 02-0036 EA279, 2006.

[12] N. A. Buang, Asas keusahawanan, Kuala Lumpur: Fajar Bakti Sdn. Bhd, 2002.

[13] A. M. Said, "Penilaian kurikulum pendidikan islam politeknik kementerian pengajian tinggi," Ph.D. Thesis, Universiti Kebangsaan Malaysia, Bangi, 2010.

[14] A. Yahya,"Keberkesanan pelaksanaan program Kemahiran Hidup di sekolah-sekolah menengah di Malaysia berdasarkan Model Penilaian KIPP," Ph.D. Thesis, Universiti Putra Malaysia,1999.

[15] N. H. Othman, M. H. Amiruddin and M. Mansor, "The entrepreneurial behavior of Orang Asli youths in South Peninsular Malaysia," International Journal of Education and Information Technologies, vol 5, pp. 132-139, 2011.

[16] Ontario, Ministry of Education, 2006.

[17] N. H. Othman, "Keberkesanan program keusahawanan remaja di sekolah menengah,” Ph.D. Thesis, Universiti Putra Malaysia, 2002.

[18] Ministry of Higher Education Malaysia. Tracer studies on graduates of community colleges, Section of Industrial Relations, Tracer and Alumni, Department of Community College Education, Ministry of Higher Education, Putrajaya, 2009.

[19] N. H. Othman and H. Harun, Keusahawanan Remaja Malaysia, Serdang: Penerbit Universiti Putra Malaysia, 2007

[20] M. H. Amiruddin and N. H. Othman, "Meninjau keperluan pendidikan keusahawanan berdasarkan kepada perspektif belia orang asli di selatan Malaysia," in Proc. 2nd World Congress on Teacher Education for TVET, Batu Pahat, 2010, pp. 99-116.

[21] C. C. Edwards, "Assessing entrepreneurships and African American women: Factors of success," Ph.D. Dissertation, Northcentral University, Arizona, USA, 2008.

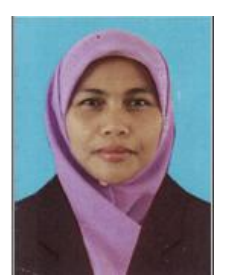

Rasmuna Hussain is currently a lecturer in Business Accounting Education at the Kuala Langat Community College, Selangor. She is presently pursuing her studies in Ph.D. of business and entrepreneurship education at the Universiti Kebangsaan Malaysia.

She also obtained her masters of business and entrepreneurship education from Universit Kebangsaan Malaysia and her bachelor of business administration \& economics, majoring in Finance from California State University, Sacramento, USA. She has been presenting several papers in international and national seminars and conferences. Her research interests include teaching and learning strategies, entrepreneurship, entrepreneurial intention and business venturing.

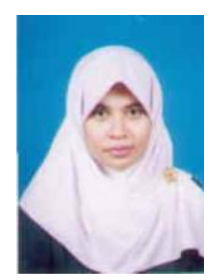

Norasmah Othman obtained her bachelor's degree in finance from the University of Minnesota, Minnesota, USA. She received her master's in finance from the University of New Haven, Connecticut, USA and her Ph.D. in entrepreneurship education and assessments from University Putra Malaysia, Malaysia.

She is currently an associate professor in Business and Entrepreneurship Education at Faculty of Education, Universiti Kebangsaan Malaysia,Bangi, Malaysia. She has written many journals articles, books, book chapters and papers at the national and international levels in the area of entrepreneurship education. 